удк 332.13

\title{
ПОЛІПШЕННЯ ЯКОСТІ ПІДПРИЄМНИЦЬКОГО СЕРЕДОВИЩА НА РЕГІОНАЛЬНОМУ РІВНІ ЯК ФАКТОР РОЗВИТКУ ТУРИСТИЧНОЇ ГАЛУЗІ
}

\section{IMPROVING THE QUALITY OF THE ENTREPRENEURIAL ENVIRONMENT AT THE REGIONAL LEVEL AS A FACTOR IN THE DEVELOPMENT OF THE TOURISM}

\author{
Полусмяк Юлія Ігорівна \\ кандидат економічних наук, доцент, \\ Запорізький національний університет \\ ORCID: https://orcid.org/0000-0002-7521-6418 \\ Зенкіна Рада Юріївна \\ студентка, \\ Запорізький національний університет \\ ORCID: https://orcid.org/0000-0001-5915-1530 \\ Polusmiak Yuliya, Zenkina Rada \\ Zaporizhzhia National University
}

Проблема створення сприятливого середовища для розвитку та ведення бізнесу в Україні та її регіонах $\epsilon$ актуальною, тому що це $є$ необхідною передумовою для досягнення країною більш високого рівня економічного розвитку та інтеграції до спільного ринку ЄС. Підприємництво, малий та середній бізнес (МСП) $є$ головним активом економік всіх розвинених країн світу. Чітко визначені та прозорі «правила гри» на ринку, чесна та передбачувана поведінка контрольних органів, відсутність регуляторних бар'єрів $€$ необхідними для повноцінного розвитку підприємництва та залучення інвестицій, зокрема до туристичної галузі [8]. У статті визначено проблемні питання, які гальмують розвиток бізнесу, досліджено основні бар'єри, що перешкоджають розвитку МСП, в тому числі туристичної галузі, на регіональному рівні, проаналізовано основні структурні показники діяльності малих підприємств окремих регіонів України.

Ключові слова: підприємництво, туризм, туристична галузь, інфрраструктура, бізнес-клімат, підприємницьке середовище, регіон, бізнес, влада.

Проблема создания благоприятной среды для развития и ведения бизнеса в Украине и ее регионах является актуальной, так как это является необходимым условием для достижения страной более высокого уровня экономического развития и интеграции в общий рынок ЕС. Предпринимательство, малый и средний бизнес (МСП) является главным активом экономик всех развитых стран мира. Четко определенные и прозрачные «правила игры» на рынке, честная и предсказуемое поведение контролирующих органов, отсутствие регуляторных барьеров необходимы для полноценного развития предпринимательства и привлечения инвестиций, в том числе в сореру туризма [8]. В статье определены проблемные вопросы, которые тормозят развитие бизнеса, исследованы основные барьеры, препятствующие развитию Мсп на региональном уровне, включая сореру туризма, проанализированы основные структурные показатели деятельности малых предприятий отдельных регионов Украины.

Ключевые слова: предпринимательство, туризм, туристическая сфера, инфраструктура, бизнес-климат, предпринимательская среда, регион, бизнес, власть.

The problem of creating a favorable environment for business development and business in Ukraine and its regions is relevant, because it is a necessary prerequisite for the country to achieve a higher level of economic development and integration into the EU common market. Entrepreneurship, small and medium business (SME) is the main asset of the economies of all developed countries. Clearly defined and transparent "rules of the game" in the market, honest and predictable behavior of regulatory authorities, the absence of regulatory barriers are necessary for the full development of entrepreneurship and investment including in the sphere of tourism [8]. The natural environment for effective and stable development of SMEs is a market economy with its inherent developed regulatory 
and economic regulators, as well as the relevant infrastructure, which is divided into organizational and technical, financial and credit and information and analytical components. Entrepreneurship infrastructure creates favorable conditions for its development in the state. But in Ukraine in general and in the regions in particular there is no qualitative improvement of the infrastructure of the business environment. And it is the development and qualitative improvement of the above components of the infrastructure that we consider to be priority areas for improving the quality of the business environment at the regional level. The middle environment for effective and stable development of SMEs is a market economy with its inherent developed regulatory and economic and economic regulators, as well as the relevant infrastructure infrastructure-analytical-information. Improving the mechanism for providing public financial support to SMEs in Ukraine should be based on the experience of the EU and the US, using both direct financing instruments and indirect financial support instruments. The article identifies problematic issues that hinder business development, explores the main barriers to the development of SMEs at the regional level, analyzes the main structural indicators of small businesses in some regions of Ukraine.

Keywords: entrepreneurship, tourism, tourist sphere, infrastructure, business climate, business environment, region, business, government.

Постановка проблеми. Розвиток підприємництва, як специфрічної сорери ринкових відносин відіграє важливу роль у забезпеченні постійного та збалансованого розвитку областей України в цілому, так і в поліпшення якості підприємницького середовища зокрема. Безперервний розвиток підприємницької ссрери позитивно впливає на конкурентне середовище суб'єктів підприємництва в системі економіки регіонів, для яких створюються умови та ресурсний потенціал за для ефективного їх фрункціонування, з'являється зацікавленість з боку вітчизняних та іноземних інвесторів. Особливо це $\epsilon$ актуальним та важливим для розвитку туристичної галузі.

Аналіз останніх досліджень і публікацій. Питання поліпшення якості підприємницького середовища на регіональному рівні, розвитку малого та середнього підприємництва та підвищення його конкурентоспроможності досліджувалась у роботах вітчизняних учених, зокрема: І. Баланюка, В. Варцаби, Л. Газуди, В. Готри, Б. Дяченко, Г. Кампо, Л. Ковальської, М. Лендєла, В. Марачова, О. Сідуна, М. Чумаченка та інших. Але в роботах зазначених авторів комплексне й системне дослідження теоретичних, методичних і практичних аспектів розвитку малого підприємництва в контексті регіональних пріоритетів не було висвітлено.

Метою статті $\epsilon$ дослідження складових інфрраструктури як пріоритетних напрямів поліпшення якості підприємницького середовища на регіональному рівні (на прикладі Запорізької, Дніпропетровської, Донецької та Харківської областей), які будуть мати позитивний вплив на розвиток туристичної галузі.

Виклад основного матеріалу дослідження. Стабільний розвиток підприємництва $€$ запорукою становлення конкурентоспроможної економіки регіону та держави загалом, що $є$ основою успішного суспільства та вимагає сприятливого бізнес-клімату. Так, у
Європейському Союзі до сегменту малих та середніх МСП припадає 99.8\% усіх підприємств, $66.8 \%$ зайнятих та $57.8 \%$ доданої вартості. Але, незважаючи на деяке покращення середовища ведення бізнесу в нашій країні, про що свідчить її підняття в рейтингу ведення бізнесу у 2019 році на 5 позицій, порівняно із 2018 роком, Україна все ще значно відстає від передових країн світу. Особливо складними впродовж останніх років $є$ вирішення проблем із неплатоспроможністю, підключення підприємств до електромереж, а також проблеми у сорері міжнародної торгівлі (за цими показниками Україна посіла у 2019 році відповідно 145, 135 та 78 місце серед 190 країн світу).

Згідно з результатами дослідження, проведеного Мінекономрозвитку та Офрісом ефективного регулювання, ситуація з МСП в Україні схожа на ситуацію в Європейському Союзі: близько 99\% суб'єктів господарської діяльності являють собою малі та середні підприємства, у сегменті зайняті 4.2 млн українців тобто $72 \%$ від всієї комерційної зайнятості. Всього ж на українські МСП припадає $42 \%$ обсягів реалізації товарів, робіт та послуг.

Позитивні тенденції зростання кількості малих підприємств, найманих працівників, фрактичних і реальних обсягів реалізованої продукції підштовхують до поглибленого дослідження досвіду регіональної політики та пошуку нових шляхів розвитку підприємницької діяльності у Запорізькому регіоні та Україні в цілому. Слід зауважити, що впродовж останніх декількох років на макрорівні відбуваються позитивні зміни в процесі поліпшення бізнесклімату в країні, а саме:

- 1298 нормативно-правових актів переглянуто на користь бізнесу в рамках дерегуляції (суттєво спрощені умови для підприємств у сорері будівництв, енергетики, транспорту та індрраструктури, інфрормаційних технологій та телекомунікацій); 


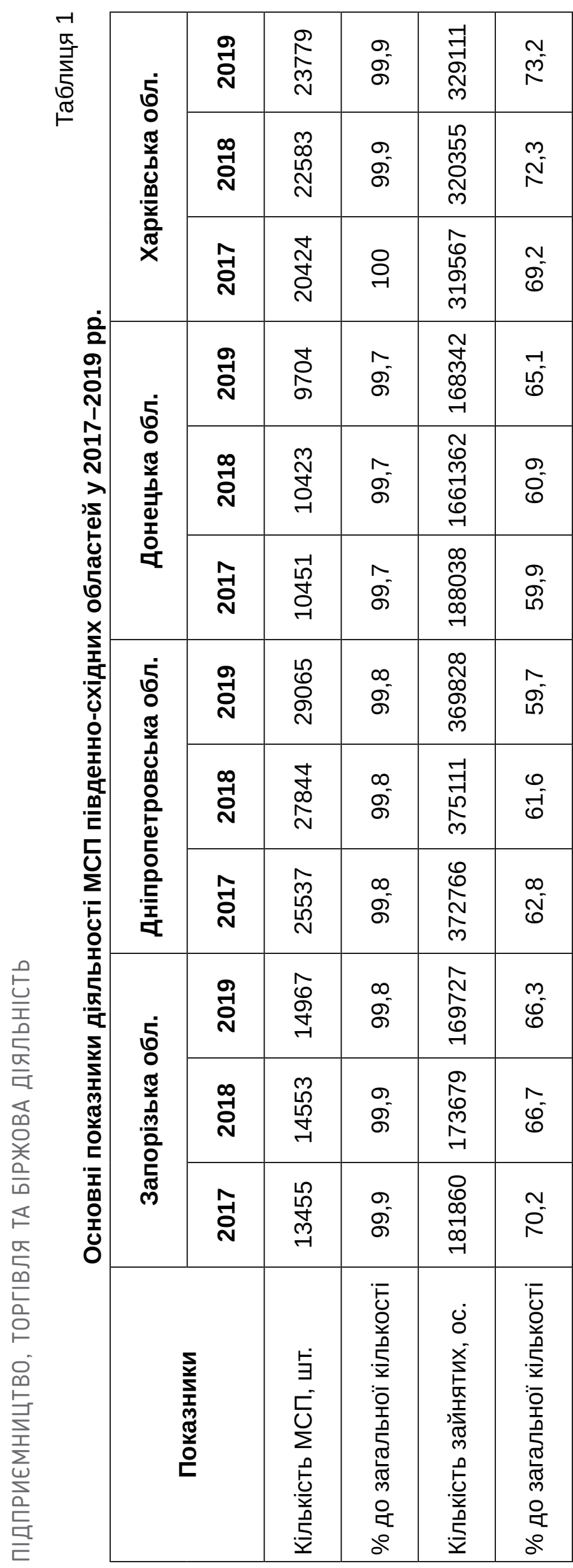

- впроваджено ризико-орієнтований підхід до перевірок бізнесу. Частота та детальність перевірок контролюючими органами базується на ступені ризику від діяльності підприємств, а не на простій фріксації порушень;

- запущено Офріс підтримки малих та середніх підприємств (SMEDO), завданнями якого $€$ створення центрів підтримки підприємництва, впровадження механізму часткового гарантування кредитів, запуск Державного інфрормаційного порталу для МСП;

- запущено Інспекційний портал, завдяки чому всі дані про плановані перевірки та їх результати доступні онлайн.

Проте питання щодо якісного поліпшення підприємницького середовища на регіональному рівні залишається відкритим та потребує подальшого дослідження. Особливо це стосується регіонів, які знаходяться на сході України, межують з зоною проведення Операції Об'єднаних сил та економіка яких найбільш постраждала від воєнних дій на сході України.

Поліпшення бізнес-клімату в країні має позитивний вплив на розвиток підприємництва та підвищення його конкурентоспроможності, що відіграє велику роль в процесі подолання проблем, які постають перед економікою українських міст та регіонів. Це стосується і туристичної галузі, оскільки розвиток туризму в нашій країні гальмується через низку негативних чинників, зокрема недостатню підтримку розвитку підприємництва в туристичній сорері 3 боку держави, брак інвестицій як наслідок несприятливого бізнесклімату, відсутність дієвих програм розвитку МСП у ссрері готельного та ресторанного обслуговування.

Проаналізуємо кількість малих та середніх підприємств південно-східних областей України, зокрема в Запорізькій, Дніпропетровській, Донецькій та Харківській областях та кількість працівників, зайнятих в МСП (табл. 1).

Як видно 3 таблиці, динаміка приросту кількості малих та середніх підприємств у Запорізькій, Дніпропетровській та Харківській областях $€$ позитивною. Темп приросту у 2019 р. до 2017 р. в Запорізькій області становить 11\%, Дніпропетровській - 12\%, Харківській - 14 \%. У Донецькій області спостерігається зниження кількості МСП (на 7\% за 3 роки). Таким чином, аналіз статистичних даних показав незначне збільшення кількості МСП у трьох областях з чотирьох, але темпи приросту $€$ незначними. Більш тривожним фрактором $€$ скорочення кількості зайнятих в 
МСП. Мале та середнє підприємництво - це інструмент самозайнятості населення, який створює нові робочі місця, сприяє підвищенню ділової активності та покращенню рівня життя населення, є дієвим засобом зменшення прихованого безробіття. В розвинутих країнах світу кількість зайнятих в МСП становить 70-80\% (в країнах ЄС 72\% з загального числа зайнятих, в Японії - 78\%).

3 наведених вище даних можна зробити висновок, що зайнятість в МСП скоротилося в Запорізькій області на 7\%, Дніпропетровській - на 1\%, Донецькій області - на 11\%. Тільки в Харківській області кількість зайнятих зросла на 2\%. Саме розвиток підприємництва сприяє підвищенню ділової активності населення, в тому числі середнього класу, який $€$ основою проведення соціальних та економічних ресрорм, забезпечує стабільність суспільства, позитивно впливає на розвиток людського капіталу, процес демократизації суспільства, раціоналізацію економічної організації та управління [4].

Природним середовищем ефективного та стабільного розвитку МСП $є$ ринкова економіка з притаманними їй розвиненими нормативно-правовими та економічними регуляторами, а також відповідною інсрраструктурою, яку поділяють на організаційно-технічну, фрінансову-кредитну та інфрормаційно-аналітичну складові. Інсрраструктура підприємництва створює сприятливі умови для його розвитку в державі. Але в Україні в цілому та в регіонах зокрема якісного поліпшення інсрраструктури підприємницького середовища не відбувається. I саме розвиток та якісне поліпшення зазначених вище складових інсрраструктури вважаємо пріоритетними напрямами поліпшення якості підприємницького середовища на регіональному рівні.

Відповідно до чинного законодавства України, зокрема Закону України «Про розвиток та державну підтримку малого і середнього підприємництва в Україні» [9], в регіонах, що досліджуються, розроблені та діють регіональні програми розвитку малого і середнього підприємництва, що $€$ позитивним фрактором. В регіональних програмах більшу долю займає аналіз стану і проблем підприємництва в регіонах. При цьому наводиться значний масив статистичних даних, однак за результатами кількісного аналізу практично не наводяться висновки щодо пріоритетів політики розвитку МСП. Характеристика конкурентних переваг та обмежень перспективного розвитку регіону, розроблення стратегічного плану розвитку здійснюється на основі діагнозу стартових умов регіонального розвитку шляхом SWOT-аналізу. Лише у програмі розвитку Донецької області в аналітичному блоці наводяться результати SWOT-аналізу, який, на наш погляд, $€$ необхідною та показовою складовою стратегічних програм. В програмах Запорізької, Дніпропетровської та Харківської області SWOT-аналіз відсутній.

Необхідною складовою регіональних програм вважаємо виявлення основних проблем розвитку МСП.У програмі Дніпропетровської області проблеми та перешкоди розвитку малих та середніх підприємств не визначені. Це суттєве упущення, тому що головний програмний принцип не дотримано: концентрація ресурсів на вирішенні суспільно важливих проблем. Якщо проблеми не визначені, то заходи програми стають неефективними, незрозуміло що саме необхідно покращувати, які негативні ситуації будуть вирішені, які задачі та заходи мають бути запроваджені.

ще однією проблемою вважаємо, що визначення проблем розвитку МСП у регіональних програмах базується на баченні тільки працівників органів обласної влади. При розробленні програм практично не опитуються представники цього сектора для врахування їхнього бачення проблем розвитку, а також шляхів їх вирішення. У програмах не наводяться результати таких опитувань [6]. Тому можна зробити висновок, що проблеми та заходи, що описані в програмах розвитку, можуть зовсім не збігатись з реальними проблемами, які відзначають представники МСП у регіоні.

Потрібною умовою досягнення прописаних цілей та передбачуваних результатів усіх програм розвитку $€$ їх фрінансове забезпечення, яке включає пошук доступних та мобілізацію наявних джерел фрінансування і забезпечення поетапного надходження коштів для виконання програмних заходів. Місцевим державним адміністраціям та органам місцевого самоврядування рекомендовано виділяти не менше 0,5\% від річних доходів відповідних бюджетів для підтримки розвитку МСП. Як показують дані обчислень, на фрінансування програм розвитку МСП повинні спрямовуватись набагато більші обсяги бюджетних коштів, ніж фрактично виділяються [6].

В інфрраструктурі підприємницького середовища важливе місце займають срінансовокредитні установи (банки, біржі, інвестиційні фонди, кредитні установи та спілки). Аналіз орінансових інструментів державної підтримки 
МСП, що застосовуються в Україні та регіонах показав, що вони використовуються неефективно, їх перелік не $€$ достатнім та державні програми підтримки позбавлені достатнього обсягу фрінансування.

Діяльність фондів та установ, які реалізують фрінансову політику підтримки МСП є неефективною через недостатнє фрінансування, відсутність контролю як за установою, що видає кредити, так і за суб'єктом господарювання, що використовує кредитні кошти, відсутність диверсифрікованих інструментів фрінансової підтримки. Необхідним є запровадження ефективних фрінансових послуг на рівні державних інститутів підтримки малого підприємництва. Фонди мікрокредитування, хоч і є найпоширенішими в Україні, за відсутності державного фрінансування виявилися неефективними. Актуальним для нашої країни $€$ створення фрондів гарантування кредитів. В них держава $€$ гарантом певної частини кредиту, а кредитування здійснюється за рахунок банків. Діяльність таких орондів має бути побудована 3 дотриманням принципів єдності із економічними програмами розвитку, системності у підході до управління фрінансовими ресурсами та моніторингу досягнення цілей [11, с. 86].

Крім того в Україні працює Державний фонд регіональний розвитку, який також здійснює фрінансову підтримку МСП в регіонах. Але в діяльності ДФРР також $є$ недоліки. Так в Донецькій області на кінець 2019 р. залишився найбільший залишок нерозподілених коштів - 132 млн гривень, в м. Києві-93,3 млн. гривень, в Харківській області - 24,5 млн грн., Херсонській області - 13,4 млн грн., оскільки пропозиції щодо розподілу коштів державного фонду регіонального розвитку на весь передбачений для регіону обсяг цими облдержадміністраціями на сьогодні - не надано [8].

Вважаємо, що вдосконалення механізму надання державної фрінансової підтримки МСП в Україні повинно будуватись 3 урахуванням досвіду країн ЄС та США, застосовуючи як інструменти прямого фрінансування так і інструменти непрямої фрінансової підтримки. Позитивним можна вважати досвід країн ЄС, які використовують розгалужене фрінансування МСП за рахунок різноманітних європейських інституцій та розроблених ними програм.

Ще однією необхідною і дуже важливою складовою ефективної діяльності МСПє інорормаційна підтримка, яка найкраще розкривається шляхом підтримки мережі інформаційно- аналітичних центрів МСП. Такі центри повинні надавати інформаційну підтримку щодо складання звітності, основних норм ПКУ та інших нормативно-законодавчих актів, а також надавати інформацію щодо стану ринку, в тій чи іншій сорері. На основі зазначеної інфрормації керівництво МСП мало б змогу орієнтуватися у прийнятті стратегічних рішень та фрункціонувати більш ефрективно. Тому, на нашу думку, державна та регіональна влада повинна сприяти розвитку інфрормаційно-аналітичної інфрраструктури підприємницького середовища, a саме: запровадження нових каналів комунікації між бізнесом та владою (наприклад, розсилки через електронну пошту), удосконалення існуючих механізмів інфрормування підприємців про заходи та рішення, які впливають на діяльність бізнесу; активне залучення представників бізнесу та бізнес-асоціацій до розробки та публічного обговорення стратегічних документів та рішень, що стосуються діяльності МСП (передусім програм розвитку малого та середнього бізнесу).

Удосконалення каналів та механізмів комунікації між бізнесом та владою повинно відбуватися з урахуванням потреб обох сторін. Індикатором ефективності діалогу влади й бізнесу є відкритість (прозорість), підзвітність та передбачуваність діяльності місцевої влади, 3 одного боку, та здатність бізнесу цивілізовано захищати свої інтереси - 3 іншого. Можливість прозоро й на рівних умовах використовувати комунальне майно та земельні ділянки комунальної власності для ведення підприємницької діяльності. Однією з головних проблем у відносинах «влада-бізнес» $є$ проблема прозорого доступу до інсрормації про комунальне майно та вільні земельні ділянки. Наявність вільного та простого доступу до актуальної інорормації про комунальні ресурси в електронному вигляді $\epsilon$ необхідною умовою підтримки розвитку підприємництва в місті. Для досягнення цілі заплановано створення прозорого публічного доступу до інформації про комунальне майно та вільні земельні ділянки, які можуть використовуватись у підприємницькій діяльності, а також залучення суб'єктів МСП до закупівель, що здійснюються за рахунок бюджету.

Високий регуляторний тиск на малі та середні підприємства $€$ однією 3 головних перешкод для розвитку нинішніх суб'єктів підприємницької діяльності та, особливо, підприємців-початківців, що ускладнює створення нових суб'єктів. Як показують опитування в регіонах, що досліджуються, несприятливий 
регуляторний клімат та високий регуляторний тиск - це головні перешкоди на думку підприємців. Ці перешкоди були названі 35,9\% та $19 \%$ опитаних підприємств відповідно. Оскільки адміністративні витрати на ведення бізнесу складають значну частину всіх витрат, зменшення регуляторного навантаження 3 , одного боку, зменшить витрати, а з іншого сприятиме заснуванню бізнесу.

Радикальне поліпшення регуляторного середовища $€$ одним із найважливіших чинників реалізації приватної підприємницької ініціативи, особливо для сектору МСП. Таке поліпшення регуляторного клімату має стати постійним триєдиним процесом. Мова йде про скасування регуляторних актів, які створюють невиправдані бар'єри для розвитку бізнесу та стимулюють корупцію; модифрікацію (коригування) чинного законодавства; прийняття нових регуляторних норм. Ефрективність цього процесу, серед іншого, залежить від рівня дотримання відповідного законодавства бізнесом та державою. А важливим показником успішності ресоормування бізнес-середовища може стати міжнародна «конкурентоспроможність» регуляторного режиму України.

Однією 3 складових аналізу регуляторного впливу (AРB) $€$ М-тест, який $€$ реалізацією одного 3 принципів «спочатку думай про мале». Це інструмент аналізу можливих наслідків впливу законодавчих ініціатив на
МСП, який передбачає консультації з експертами та представниками бізнесу тощо. В ході аналізу використання М-тесту для оцінки впливу регуляторного акту на МСП в регіонах, що досліджуються, виявлено, що він реалізується неефективно. М-тест подібний до МСП-тесту в країнах Європейського Союзу, але поширюється тільки на мікро- і малі підприємства, охоплюючи тільки витрати, без прибутків. Методологія М-тесту потребує вдосконалення та ефрективного застосування, в тому числі шляхом підвищення обізнаності серед державних службовців.

Висновки. Таким чином, з метою активізації розвитку МСП у Запорізькій, Дніпропетровській, Донецькій та Харківській областях необхідним вважаємо врегулювання законодавчої бази, в тому числі усунення адміністративних бар'єрів, зменшення впливу регуляторного тиску на суб'єкти підприємництва, якісне поліпшення інфрраструктури підприємницького середовища, удосконалення механізму срінансової підтримки МСП, забезпечення більш тісної співпраці з органами державного управління. У процесі реалізації державної регіональної політики забезпечення есрективного функціонування, підтримки і розвитку підприємництва, вагомою є роль та відповідальність місцевих органів самоврядування у напрямі створення сприятливого підприємницького середовища в регіоні.

\section{СПИСОК ВИКОРИСТАНИХ ДЖЕРЕЛ:}

1. Закон України «Про засади державної регіональної політики» URL: https://zakon.rada.gov.ua/laws/ main/156-19 (дата звернення: 20.05.2021).

2. Закон України «Про стимулювання розвитку регіонів» URL: http://www.if.gov.ua/files/3У\%20Держ_Рег_ он_пол_т\%20\%5ВРежим\%20совместимости\%5D.pdf (дата звернення: 20.05.2021).

3. Газуда М.В., Волощук Н.Ю. Регіональний розвиток ссрери малого підприємництва : навч. посіб. Ужгород : Видавництво «ФОП Сабов А.М.», 2017. 254 с.

4. Балабенко О.В. Удосконалення механізму реалізації регуляторної політики держави щодо оподаткування господарської діяльності суб'єктів малого бізнесу. Актуальні проблеми економіки. 2008. № 7. С. 9-15.

5. Про внесення змін до деяких законодавчих актів України з питань регулювання підприємницької діяльності : Закон України від 18.09.2008 № 523-VI. Відомості Верховної Ради України (ВВР). 2009. № 6. Ст. 21.

6. Регіональні програми розвитку малого і середнього підприємництва: структура, пріоритети, фрінансування. Київ : Центр громадської експертизи, Центр міжнародного приватного підприємництва, 2015. 24 с.

7. Про державну підтримку малого підприємництва : Закон України № 2063-ІІІ від 19.10.2000 р. Відомості Верховної Ради України. 2000. № 51-52. Ст. 447.

8. Уряд розподілив кошти ДФФР між 116 проектами, що будуть завершені у 2019 році. URL: http://www.minregion.gov.ua/press/news/uryad-rozpodiliv-koshti-dfrr-mizh-116-proektami-shho-budut-zaversheniu-2019-rotsi/ (дата звернення: 20.05.2021).

9. Закон України «Про розвиток та державну підтримку малого і середнього підприємництва в Україні». URL: https://zakon.rada.gov.ua/laws/show/4618-17 (дата звернення: 20.05.2021).

10. Стратегія регіонального розвитку Запорізької області на період до 2027 року URL: https://www.zoda.gov.ua/ files/WP_Article_File/original/000126/126028.pdf (дата звернення: 20.05.2021). 
11. Volosovych, S. (2014) "State specialized funds in the system of economic programs implementation". Herald of KNUTE. Vol. 6. Pp. 84-94.

12. Варналій 3.С. Пріоритети вдосконалення державної політики розвитку малого підприємництва в Україні. Сттатегічні пріоритети. 2014. № 2. С. 49-54.

\section{REFERENCES:}

1. Zakon Ukrainy «Pro zasady derzhavnoi rehionalnoi polityky». URL: https://zakon.rada.gov.ua/laws/ main/156-19 (accessed 20.05.2021).

2. Zakon Ukrainy «Pro stymuliuvannia rozvytku rehioniv». URL: http://www.if.gov.ua/files/ZU\%20Derzh_Reh_ on_pol_t\%20\%5BRezhym\%20sovmestymosty\%5D.pdf (accessed 20 May 2021).

3. Hazuda M.V., Voloshchuk N.lu. (2017) Rehionalnyi rozvytok sfery maloho pidpryiemnytstva: navch. posib. Uzhhorod: Vydavnytstvo «FOP Sabov A.M.», 254 p.

4. Balabenko O.V. (2008) Udoskonalennia mekhanizmu realizatsii rehuliatornoi polityky derzhavy shchodo opodatkuvannia hospodarskoi diialnosti subiektiv maloho biznesu. Aktualni problemy ekonomiky, no. 7, pp. 9-15.

5. On Amendments to Some Legislative Acts of Ukraine on the Regulation of Business Activity: Law of Ukraine of September 18, 2008 no. 523-VI. Verkhovna Rada of Ukraine (BBR) Bulletin, 2009, no. 6, p. 21.

6. Rehionalni prohramy rozvytku maloho i serednoho pidpryiemnytstva: struktura, priorytety, finansuvannia. Kyiv: Tsentr hromadskoi ekspertyzy, Tsentr mizhnarodnoho pryvatnoho pidpryiemnytstva, 2015. 24 p. Bibliohrafiia: p. 2.

7. Pro derzhavnu pidtrymku maloho pidpryiemnytstva: Zakon Ukrainy no. 2063-III vid 19.10 .2000 r. Vidomosti Verkhovnoi Rady Ukrainy, 2000, no. 51-52, st. 447.

8. Uriad rozpodilyv koshty DFFR mizh 116 proektamy, shcho budut zaversheni u 2019 rotsi. URL: http://www.minregion.gov.ua/press/news/uryad-rozpodiliv-koshti-dfrr-mizh-116-proektami-shho-budut-zaversheni-u-2019-rotsi/ (accessed 20 May 2021).

9. Zakon Ukrainy «Pro rozvytok ta derzhavnu pidtrymku maloho i serednoho pidpryiemnytstva v Ukraini». URL: https://zakon.rada.gov.ua/laws/show/4618-17 (accessed 20 May 2021).

10. Regional development strategy of Zaporizhzhia region for the period up to 2027. URL: https://www.zoda.gov.ua/ files/WP_Article_File/original/000126/126028.pdf (accessed 20 May 2021).

11. Volosovych S. (2014) "State specialized funds in the system of economic programs implementation". Herald of KNUTE, vol. 6, pp. 84-94.

12. Varnalii Z.S. (2014) Priorytety vdoskonalennia derzhavnoi polityky rozvytku maloho pidpryiemnytstva v Ukraini. Stratehichni priorytety, no. 2, pp. 49-54. 